\title{
The Occurrence of Thermal Bridges in Hemp-lime Construction Junctions
}

\author{
Magdalena Grudzińska1*, Przemysław Brzyski \\ ${ }^{1}$ Department of Construction, \\ Faculty of Civil Engineering and Architecture \\ Lublin University of Technology, \\ Nadbystrzycka St. 40, 20-618 Lublin, Poland \\ *Corresponding author, e-mail: m.grudzinska@pollub.pl
}

Received: 30 October 2018, Accepted: 11 January 2019, Published online: 13 February 2019

\begin{abstract}
Thermal bridges increase heat losses in buildings and reduce the temperature of the internal envelope surface, causing moisture condensation and mould growth. This is an important issue for building materials based on organic components such as a hemp-lime composite, as they are particularly susceptible to biological degradation.

The hemp-lime composite is used as a filling in timber frame construction. The increased cross-section of wooden elements together with the geometry change in the construction joints can form thermal bridges. The paper presents numerical analyses of temperature distribution in the area of construction elements connections, taking into account several variants of junctions: external walls, corners, and window placement in a wall. The thermal parameters of hemp-lime composites used in the analyses were obtained from the authors' own research.

Despite relatively good insulating properties, timber elements have a noticeable influence on the local increase of the heat transfer in hemp-lime composite structures, forming thermal bridges in the partitions themselves and in the construction nodes. However, the linear thermal transmittance coefficients in the presented joints were not very significant (in the range of $0.026 \div 0.092 \mathrm{~W} /(\mathrm{m} \cdot \mathrm{K}$ ) depending on the type of connection), proving the usefulness of this type of construction in energy-efficient buildings.
\end{abstract}

\section{Keywords}

hemp-lime composites, timber frame construction, thermal bridges, construction junctions, thermal conductivity

\section{Introduction}

Despite the use of increasingly efficient insulating materials, heat losses during the heating season are significantly influenced by the "weak points" in the building envelope [1]. These week points are known as thermal bridges, which means the area where heat and/or cold is transferred at a substantially higher rate than through the surrounding envelope area. According to the literature, thermal bridges may cause up to $30 \%$ of the extra-thermal losses through the envelope in winter, therefore increasing the energy demand for heating [2]. Potential thermal bridges in the building structure are the construction elements' junctions: connection of the external wall with the roof, the ceiling, the floor on the ground, the windows and corners.

In the areas subject to excessive heat flow, temperature reduction on building elements' surfaces occurs. This is followed by an increased risk of surface condensation as well as interstitial condensation and mold growth in the wintertime, reducing indoor air quality [3-6]. These phenomena are especially dangerous in the case of walls made of material based on plant ingredients, as they are particularly susceptible to biological corrosion. Examples are materials such as strawbale, a mixture of clay and straw, and hemp-lime composite. Natural building technologies (strawbale or hempcrete) use a timber frame as a load-bearing construction, usually covered with insulating material. The thermal conductivity coefficient of the wood is about $0.16 \mathrm{~W} /(\mathrm{m} \cdot \mathrm{K})$ [7], so there is a small difference in comparison with the thermal conductivity coefficient of, for example, straw $-0.073 \mathrm{~W} /(\mathrm{m} \cdot \mathrm{K})$ [8], hemplime composite $-0.082 \div 0.151 \mathrm{~W} /(\mathrm{m} \cdot \mathrm{K})$ [9], or a mixture of clay and straw $0.071 \div 0.12 \mathrm{~W} /(\mathrm{m} \cdot \mathrm{K})$ [10]. In the hemplime wall, due to the stiffness provided by the composite, 
the cross-sections of the studs is often reduced in comparison with traditional timber construction with insulation such as mineral wool [11]. However, in the junctions there is a need to reinforce the construction with additional timber elements, so these areas can become potential thermal bridges.

\section{Current knowledge about hemp-lime composites}

Hemp-lime composite is a relatively new material, and in many countries only the first buildings using this material have been built. This technology is most developed in France and in the UK. The composite has been tested in many aspects, for example: mechanical properties depending on the composition [12-14], maturation time and curing conditions [12]. The material achieves a flexural strength of $0.08 \div 0.20 \mathrm{MPa}[13,15]$ and a compressive strength of $0.15 \div 0.83 \mathrm{MPa}[15,16]$. The study also included moisture properties such as capillary uptake [15-17], water vapor diffusivity [18-21] and sorption properties [20, 21]. Because of the insulating character of the material, the thermal insulation properties (thermal conductivity coefficient) have been tested, depending on the composition of mixtures $[13,18,22,23]$, moisture content [19, 24], water content [23], method of compaction [14], compression ratio [25] and hemp shives fraction [22]. According to the literature, the obtained $\lambda$ values for hemp-lime composites are in the range of $0.074 \div 0.138 \mathrm{~W} /(\mathrm{m} \cdot \mathrm{K})[13,15,22]$.

In addition to laboratory tests of the composite, simulations of construction elements or experimental buildings made of this material were conducted, defining actual environmental conditions. The results of a hygrothermal test of an experimental building with a usable area of $27 \mathrm{~m}^{2}$ under real conditions are described in [26]. Maalouf et. al [27], in turn, examined the transient hygrothermal behavior of a hemp concrete building envelope (wall of $360 \mathrm{~mm}$ thickness) in summer in France, taking into account different outdoor and indoor conditions. A heat-air-moisture (HAM) simulation of a room with space area of $15 \mathrm{~m}^{2}$ with hemplime wall (thickness of $300 \mathrm{~mm}$ for external and $200 \mathrm{~mm}$ for internal wall) was also conducted, and the simulation model was used to analyze the impact of hemp concrete on indoor air humidity and air-conditioning loads [28].

There is a lack of research and analysis on the impact of timber elements hidden in hemp-lime envelopes on temperature distribution. Knowledge about thermal bridges in such combinations of two materials is necessary for more accurate heat balance calculations in buildings constructed in this technology.
The aim of the paper is to estimate the impact of different types of construction joints on temperature distribution in the connection area. The temperature distribution is analyzed in several variants of junctions typical for buildings made with a timber framework filled with a mixture of hemp and lime. The parameters of hemp-lime composites used in analyses are obtained from the authors' own research.

\section{Materials and methods 3.1 Hemp-lime composite}

Hemp-lime composite is a material composed of a binder based on lime (hydrated or hydraulic with additives), hemp shives obtained from the wooden core of industrial hemp stalks, and water. Composites are characterized by low bulk density, ranging from 350 to $630 \mathrm{~kg} / \mathrm{m}^{3}$ [29]. They are used as a filling in timber frame constructions, acting as thermal insulation.

The high thermal insulating properties of the composite are related to its high porosity in the range of $74.4 \div 80.8 \%$ [29]. The porosity of the composite is affected by the large amount of air enclosed in shives (of about $60 \%$ ), as well as pores formed between randomly arranged shives, between the shives and the matrix, and between the binder molecules [12]. Due to the cellulose contained in the shives, the composite is characterized by high heat capacity of about $1300 \mathrm{~J} /(\mathrm{kg} \cdot \mathrm{K})$, which has a positive influence on the thermal stability of the wall [18].

\subsection{Authors' research on composites and their thermal properties}

For the preparation of composites hemp shives derived from industrial hemp of the "Białobrzeskie" variety were used (Fig. 1). This is a Polish variety which was bred by the Institute of Natural Fibres and Medicinal Plants in Poznan in 1967. This variety has been adapted to Polish climatic and soil conditions. The plant is typically fibrous, reaching a height of $4 \mathrm{~m}$.

The binder consisted of hydrated lime CL90s class in an amount of $75 \%$ by weight, gypsum in an amount of $15 \%$ and pozzolan (metakaolin) in an amount of $10 \%$. Gypsum was used in order to accelerate the setting process, and pozzolan was used to achieve greater resistance to the moisture of the composites.

Two recipes of hemp-lime composites were investigated. The essential difference between them was the binder to filler ratio, as set out in Table 1. 


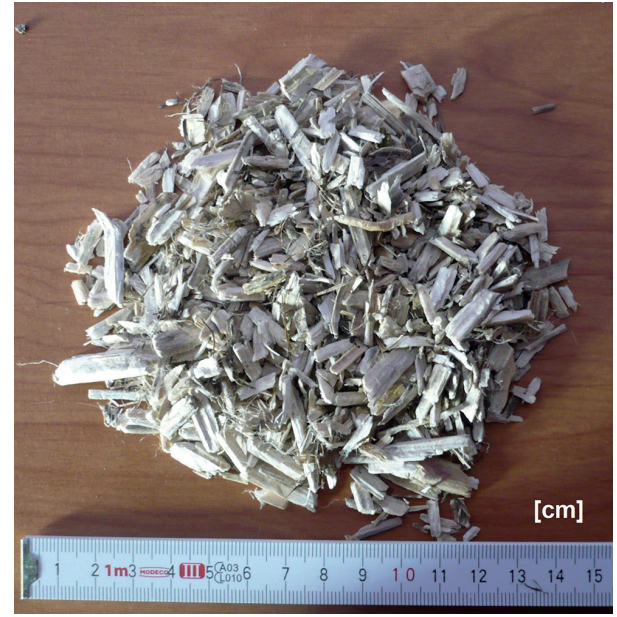

Fig. 1 Hemp shives used in the investigation

Table 1 Recipes of the hemp-lime composites

\begin{tabular}{lccc}
\hline No. & $\begin{array}{c}\text { Composite } \\
\text { symbol }\end{array}$ & $\begin{array}{c}\text { Binder : hemp shives } \\
\text { ratio (by weight) }\end{array}$ & $\begin{array}{c}\text { Binder : water } \\
\text { (by weight) }\end{array}$ \\
\hline 1. & HLC1 & $1.4: 1$ & $1: 1.45$ \\
2. & HLC2 & $1.6: 1$ & $1: 1.45$ \\
\hline
\end{tabular}

Thermal conductivity was measured in a FOX314 plate apparatus consisting of a cooling and a heating plate with a heat flux sensor in accordance with the ISO 8302 method [30]. The thermal conductivity test of the composites was carried out on specimens with dimensions of $50 \times 300 \times 300 \mathrm{~mm}$. The specimens were laid and compacted in the mold in an analogous way as in a wall (Fig. 2).

The mixture was placed in a mold and compacted in the vertical direction. The heat flux passing through the specimen arranged between the cooling and heating plates during the test was perpendicular to the compaction direction of the material. In fact, in the case of an external wall, the heat flux also flows in a perpendicular direction to the direction of compaction of the mixture in the formwork (Fig. 3).

The specimens were tested after 28 days of maturation in laboratory conditions (air temperature $20^{\circ} \mathrm{C} \pm 2{ }^{\circ} \mathrm{C}$, air relative humidity $55 \% \pm 5 \%$ ) and then were dried to a constant weight in an oven at $60^{\circ} \mathrm{C}$. The temperature set on the heating plate was $25^{\circ} \mathrm{C}$, while on the cooling plate it was $0^{\circ} \mathrm{C}$. The thermal conductivity test results were averaged over the results coming from six specimens, the final coefficients are shown in Table 2.

The thermal conductivity coefficient of the hemp-lime composite depends on the material density which, in turn, is related to the binder-to-filler ratio. As the binder content increases, the insulating properties of the material deteriorate. These observations are also described in the literature [23, 29].

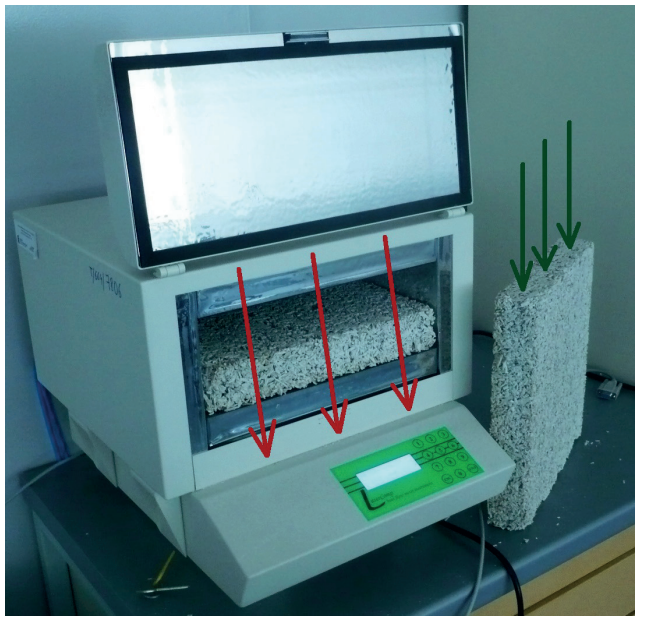

Fig. 2 The specimen placed in the plate apparatus. Direction of the heat flux during the test (red arrows) and direction of compaction of the mix during the preparing of the specimen (green arrows)

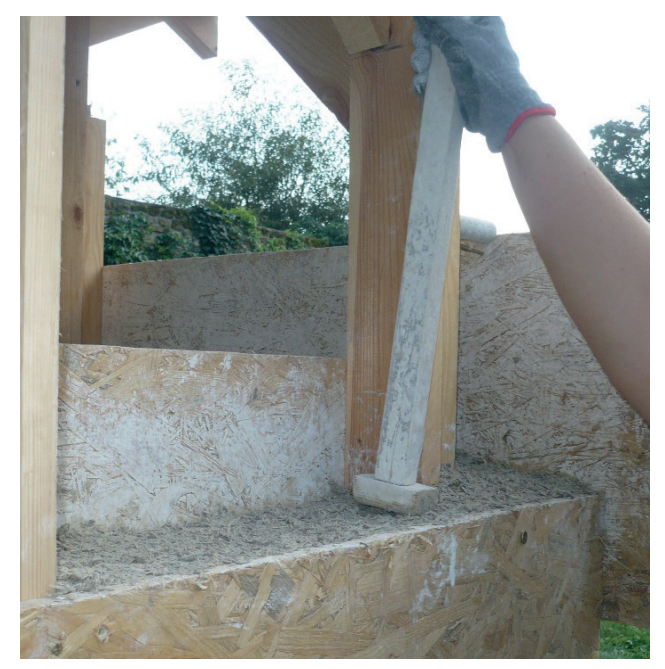

Fig. 3 Direction of compaction of the mixture in a wall formwork

Table 2 Thermal conductivity of tested composites

\begin{tabular}{lccc}
\hline No. & $\begin{array}{c}\text { Composite } \\
\text { symbol }\end{array}$ & $\begin{array}{c}\text { Thermal conductivity } \\
\text { coefficient } \\
{[\mathrm{W} /(\mathrm{m} \cdot \mathrm{K})]}\end{array}$ & $\begin{array}{c}\text { Standard deviation } \\
{[\mathrm{W} /(\mathrm{m} \cdot \mathrm{K})]}\end{array}$ \\
\hline 1. & HLC1 & 0.080 & \pm 0.002 \\
2. & HLC2 & 0.088 & \pm 0.003 \\
\hline
\end{tabular}

The obtained results were used in further computer analyses of thermal bridges as limit values for the thermal conductivity coefficient. In addition, indirect values from the $0.080 \div 0.088 \mathrm{~W} /(\mathrm{m} \cdot \mathrm{K})$ interval, namely $0.082 \mathrm{~W} /$ $(\mathrm{m} \cdot \mathrm{K}), 0.084 \mathrm{~W} /(\mathrm{m} \cdot \mathrm{K})$ and $0.086 \mathrm{~W} /(\mathrm{m} \cdot \mathrm{K})$, which are likely to be achieved using a binder to filler ratio of $1.4: 1$ to $1.6: 1$, are used to illustrate the relationship between the thermal quality of a joint and the thermal conductivity of a wall material. 


\subsection{Hemp-lime composite as an insulation filling}

The composite is used as a filling (insulation) of elements with a wooden frame construction - primarily as a wall filling, but also as roof insulation and a layer on the ground floor. Using the composite as insulation in all external elements in building, it is possible to maintain the continuity of the thermal insulation of the building envelope. The timber frame construction is usually hidden in a layer of composite or aligned with the surface of the partition. To ensure proper insulating properties of the external elements, the thickness of the composite layer is in the range of 300 to $400 \mathrm{~mm}$, depending on the national requirements regarding thermal insulation.

The structure of the walls comprises studs placed in a spacing of 400 to $600 \mathrm{~mm}$, depending on load. The studs are set on the sole plate and topped by a wall plate. The hemp-lime mixture is placed and compacted in the formwork (temporary or permanent), attached to both sides of the wall structure. Due to the composite filling, the amount of diagonal or horizontal bracing decreases. There are two typical methods of constructing walls [31-33], differing in the location of the load-bearing frame. In the first case the timber frame is placed centrally in relation to wall thickness (Fig. 4).

This solution ensures uniform distribution of loads from the wall to the frame construction. Timber elements of the frame are surrounded by hemp-lime composite, which provides protection against wood pests and biological corrosion (because of the alkalinity of lime). In the second case the load-bearing frame is located on the inner side of the external wall (aligned with the inner surface) (Fig. 5). This solution simplifies the shuttering works and also allows the installation of permanent shuttering, e.g. wood fiber board. Walls are usually finished with lime plaster from the outside and clay or lime plaster from the inside.

Construction joints included in the thermal bridges analyses are: external walls' corners and window placement in a wall. These are the most common connections of the building elements, and the presented research will concentrate on how the necessary construction reinforcements influence the heat flow and temperature distribution in the joints. All of the connections are considered for the two types of wall construction described above. Two thicknesses of hemp-lime composite layer were taken into account: $350 \mathrm{~mm}$ and $400 \mathrm{~mm}$. In all cases lime plaster on internal and external surfaces of the wall was used as a finish.

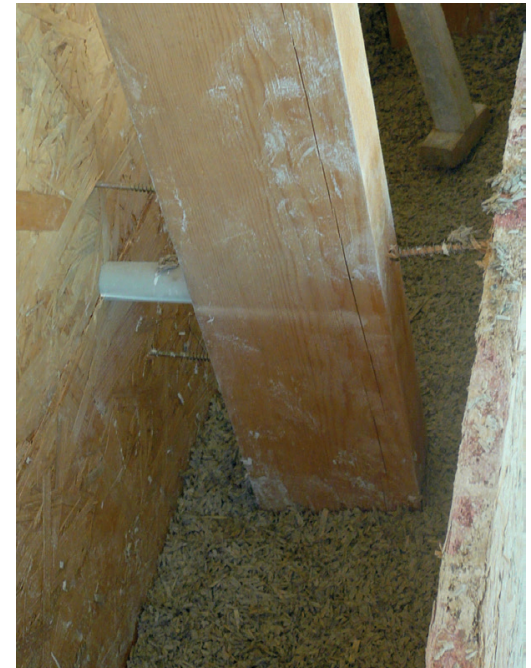

Fig. 4 Hemp-lime composite between timber studs in the middle of a wall

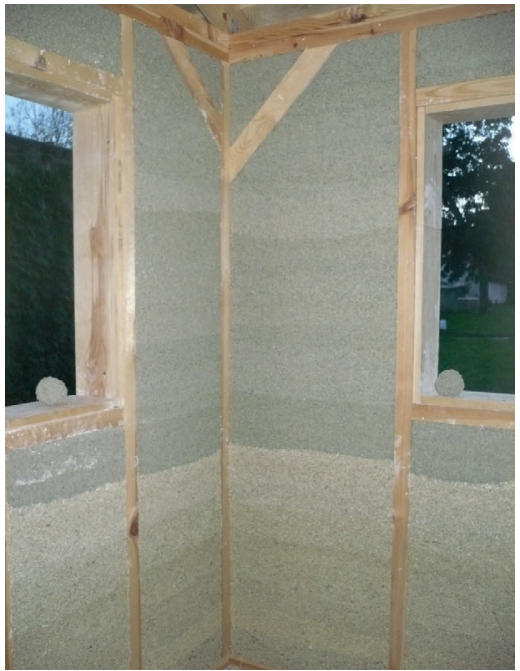

Fig. 5 Hemp-lime composite between timber studs on the inner side of the external wall

\subsection{External walls and corners}

The structure of the wall is comprised of studs with a cross-section of $50 \times 150 \mathrm{~mm}$, placed in a spacing of $500 \mathrm{~mm}$. In the corners there are higher stresses, and therefore studs of a larger cross-section must be used (three studs of $50 \times 150 \mathrm{~mm}$ joined together). Cross sections of external walls and a corner in the case of a timber frame located in the middle of the wall are shown in Fig. 6, and in the case of timber frame construction located on the inner side of the wall are shown in Fig. 7.

\subsection{Window placement in a wall (jamb)}

The window frame is attached to the timber studs with an increased cross section (two studs of $50 \times 150 \mathrm{~mm}$ located next to each other). The thermal bridge was analyzed in two variants: an aligned jamb and a jamb with a reveal. 

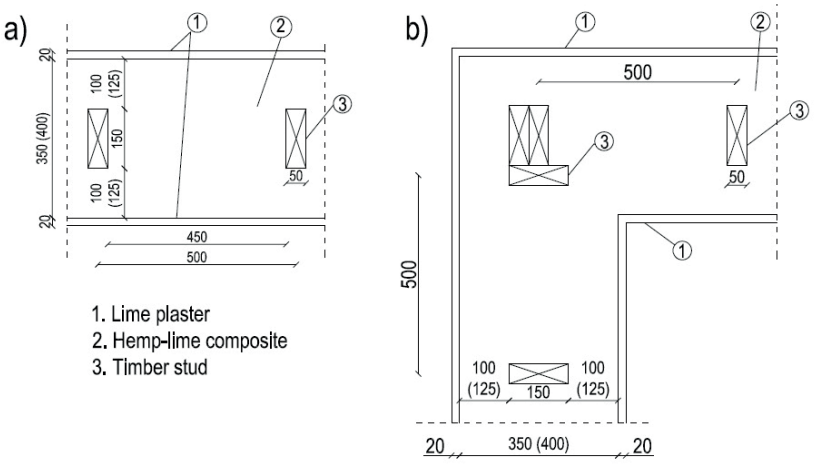

Fig. 6 External walls (a) and a corner (b) with timber frame construction located centrally in relation to wall thickness external wall
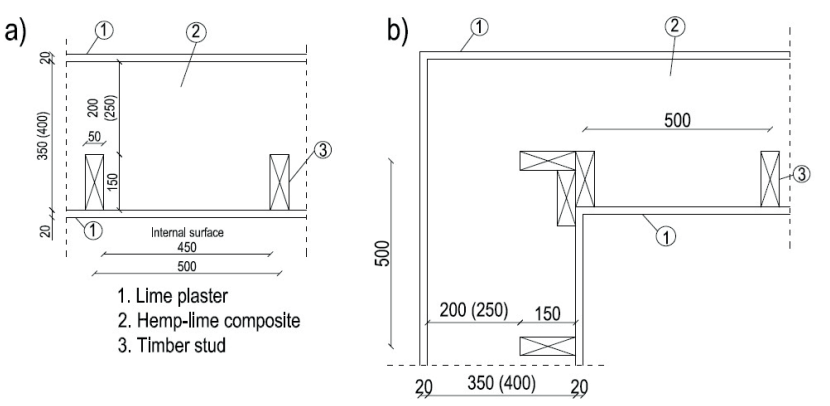

Fig. 7 External walls (a) and a corner (b) with timber frame construction located at the inner side of the wall

Fig. 8 shows window placement in the wall (jamb) in the case of a timber construction and the window frame in the center of the wall, and Fig. 9 shows window placement in the wall (jamb) in the case of a timber construction in the inner part of the wall. According to Fig. 9, it is possible to place the window frame in different positions relative to the wall thickness using an additional timber stud marked as "4" (with different cross-sections). Several situations were taken into account: the window frame placed in the center and at the outer edge of the main timber construction frame, and extended toward the outside surface of the wall by $50,100,150$ and $200 \mathrm{~mm}$.

\section{Thermal bridges modelling}

Temperature distribution in the described construction joints was calculated with the use of Therm 6.3 software [34]. This is a free software created and distributed by the Windows and Daylighting Group, Lawrence Berkeley National Laboratory, University of California, USA [35]. It was funded by the U.S. Department of Energy, and developed for 2D analyses of steady-state heat transfer through building products (such as fenestration systems and other opaque elements). Nowadays, it is commonly used in the thermal evaluation of building elements and construction joints [36-39].
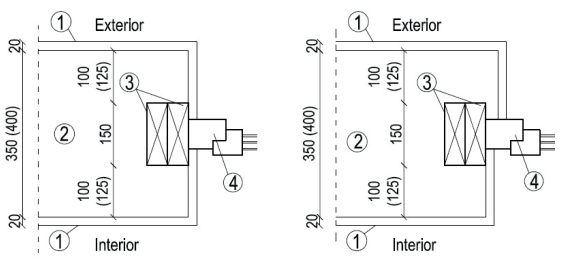

1. Lime plaster

2. Hemp-lime composite

3. Timber stud $50 \times 150 \mathrm{~mm}$

4. Window frame

Fig. 8 Window placement in the wall (jamb) in the case of a timber construction and a window frame in the center of the wall: a) without a reveal, b) with a reveal
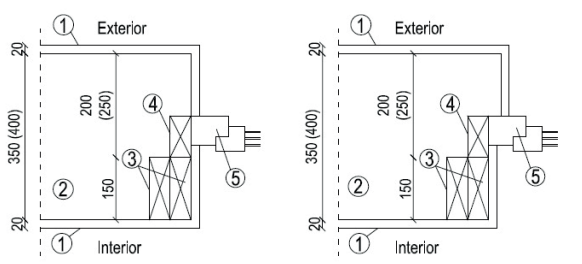

1. Lime plaster

2. Hemp-lime composite

3. Timber stud $50 \times 150 \mathrm{~mm}$

4. Timber stud $50 \times 100 \mathrm{~mm}$

5. Window frame

Fig. 9 Window placement in the wall (jamb) in the case of a timber construction in the inner part of the wall: a) without a reveal, b) with a reveal

In the code, two-dimensional heat transfer equations are solved numerically for the specific elements using the finite element method. The users have the possibility of defining their own material properties and boundary conditions, and, to some extent, of modifying automatically generated mesh in order to improve the accuracy of calculations. Glazing systems can be imported from a very wide database available in Windows software, another tool created by the same institution and based on the ISO 15099 algorithms [40].

The modelling process consists of the following stages [35]:

- model definition (including geometry definition, assignment of material properties and boundary conditions),

- mesh generation,

- calculation of temperature and heat fluxes by the Finite Element Analysis Solver,

- reporting of the post-processed results for the element.

The results are displayed in a graphical form as the isotherm and heat fluxes outline, allowing for the visual and qualitative evaluation of a thermal bridge. Information about the thermal transmittance coefficient $\left(U\left[\mathrm{~W} /\left(\mathrm{m}^{2} \cdot \mathrm{K}\right)\right]\right)$ averaged for the whole element can be used for further quantitative assessment of a joint, namely calculation of the linear thermal transmittance coefficient $\psi[\mathrm{W} /(\mathrm{m} \cdot \mathrm{K})]$.

The calculation procedure according to ISO 10211 [41] requires modelling of the element in such a way that it is extended at least $1 \mathrm{~m}$ away from the geometrical center of the thermal bridge in order to restore one-dimensional heat flow at the cut-off plane (treated as an adiabatic surface). 
If there are repeatable elements in a construction element, such as timber studs in a wall, the cut-off plane should be inserted centrally in-between them. In the pictures presented below some of the elements may be cut shorter, but this was only made for the clarity of the presentation.

The linear thermal transmittance coefficient $\psi$ is calculated as:

$\psi=L^{2 D}-\sum_{i=1}^{j} U_{i} \cdot l_{i}$,

where $L^{2 D}$ is the thermal coupling coefficient obtained from the $2 D$ analysis of the modelled element as a multiplication of the averaged thermal transmittance and the joint's length $[\mathrm{W} /(\mathrm{m} \cdot \mathrm{K})], U_{i}$ is the thermal transmittance coefficient of the i-th component of the modelled element $\left[\mathrm{W} /\left(\mathrm{m}^{2} \cdot \mathrm{K}\right)\right], l_{i}$ is the length assigned to the $U_{i}$ value (external dimensions) [m].

Thermal properties of materials and elements used in modelling together with boundary conditions are put in Tables 3 and 4 . The estimated error energy norm (related to the gradient of heat flux) of the models did not exceed $5 \%$ in all of the cases.

Table 3 Thermal properties of main materials and elements

\begin{tabular}{lcc}
\hline No. & Building material/element & Thermal properties \\
\hline 1. & Hemp-lime filling & $\lambda=0.080 \div 0.088 \mathrm{~W} /(\mathrm{m} \cdot \mathrm{K})$ \\
2. & Wooden construction element & $\lambda=0.16 \mathrm{~W} /(\mathrm{m} \cdot \mathrm{K})$ \\
3. & Lime plaster & $\lambda=0.70 \mathrm{~W} /(\mathrm{m} \cdot \mathrm{K})$ \\
4. & Window frame & $U_{f}=1.00 \mathrm{~W} /\left(\mathrm{m}^{2} \cdot \mathrm{K}\right)$ \\
5. & Glazing & $U_{g}=1.00 \mathrm{~W} /\left(\mathrm{m}^{2} \cdot \mathrm{K}\right)$ \\
6. & Window - total & $U_{w}=1.10 \mathrm{~W} /\left(\mathrm{m}^{2} \cdot \mathrm{K}\right)$ \\
\hline
\end{tabular}

Table 4 Boundary conditions used in calculations

\begin{tabular}{|c|c|c|c|c|}
\hline No. & Surface & Temperature & $\begin{array}{l}\text { Surface } \\
\text { resistance }\end{array}$ & Description \\
\hline 1. & Internal & $+21^{\circ} \mathrm{C}$ & $\begin{array}{c}0.13 \\
\left(\mathrm{~m}^{2} \cdot \mathrm{K}\right) / \mathrm{W}\end{array}$ & $\begin{array}{l}\text { Heat flow horizontal, } \\
\text { simplified* }\end{array}$ \\
\hline 2. & Internal & $+21^{\circ} \mathrm{C}$ & $\begin{array}{c}0.10 \\
\left(\mathrm{~m}^{2} \cdot \mathrm{K}\right) / \mathrm{W}\end{array}$ & $\begin{array}{l}\text { Heat flow upwards, } \\
\text { simplified* }\end{array}$ \\
\hline 3. & Internal & $+21^{\circ} \mathrm{C}$ & $\begin{array}{c}0.17 \\
\left(\mathrm{~m}^{2} \cdot \mathrm{K}\right) / \mathrm{W}\end{array}$ & $\begin{array}{l}\text { Heat flow downwards, } \\
\text { simplified* }\end{array}$ \\
\hline 4. & Internal & $+21^{\circ} \mathrm{C}$ & $\begin{array}{c}0.25 \\
\left(\mathrm{~m}^{2} \cdot \mathrm{K}\right) / \mathrm{W}\end{array}$ & $\begin{array}{l}\text { Condensation risk, } \\
\text { simplified* }\end{array}$ \\
\hline 5. & External & $-18^{\circ} \mathrm{C}$ & $\begin{array}{c}0.04 \\
\left(\mathrm{~m}^{2} \cdot \mathrm{K}\right) / \mathrm{W}\end{array}$ & Simplified* \\
\hline 6. & $\begin{array}{l}\text { Cut-off } \\
\text { planes }\end{array}$ & - & - & Adiabatic \\
\hline
\end{tabular}

* the simplified model means that convective and radiative heat exchange is described by one common surface resistance

\subsection{Results and discussion}

\subsubsection{Walls and external corners}

The thermal conductivity of timber elements is higher than that of hemp-lime filling, and the studs increase the thermal transmittance coefficient of the wall by $2.5 \%$ to $3.5 \%$. If they are considered as thermal bridges, the linear thermal transmittance coefficient varies from $0.003 \mathrm{~W} /$ $(\mathrm{m} \cdot \mathrm{K})$ to $0.004 \mathrm{~W} /(\mathrm{m} \cdot \mathrm{K})$ (Fig. 10). This seems to be a minor increase, but it must be remembered that the total length of the studs is quite big - also because of their small distance. Generally, the influence of linear thermal bridges is more pronounced if the hemp-lime filling is of lower conductivity, and the difference between the insulating properties of the two main components of the joint (that is timber and hemp-line) is bigger. The same trend occurred for the external wall corner and connection of walls and floor, the joints discussed further.
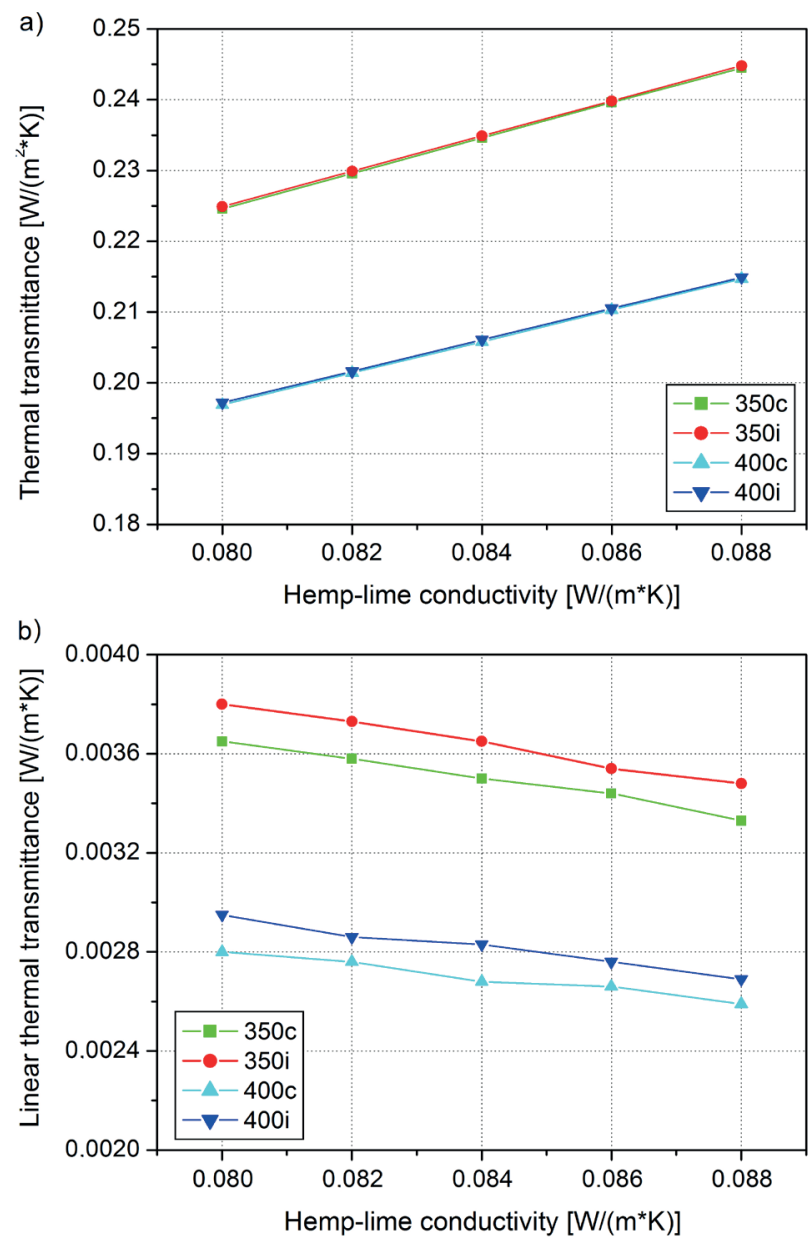

Fig. 10 Thermal properties of the wall construction: a) thermal transmittance coefficients, b) linear thermal transmittance equivalent to timber construction. Number in the legend denotes the wall thickness, c - central location of the timber frame, $\mathrm{i}$ - internal location of the timber frame 


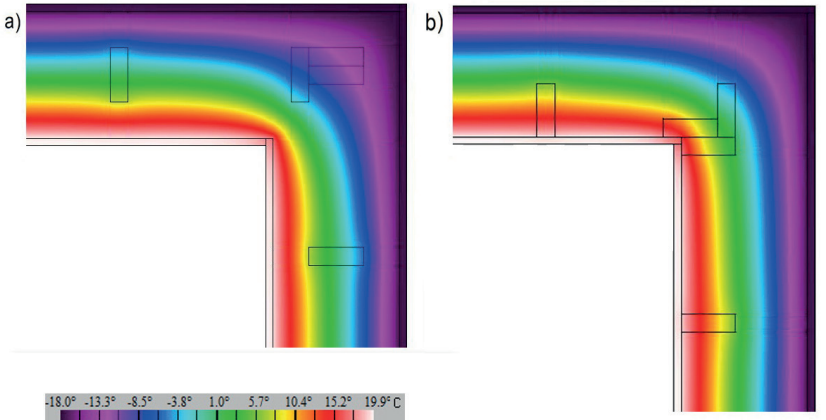

Fig. 11 Isotherms in the wall corner in the two cases of timber frame location: a) central, b) aligned with the inner plane. Wall thickness: 350 $\mathrm{mm}$, hemp-lime conductivity: $0.080 \mathrm{~W} /(\mathrm{m} \cdot \mathrm{K})$
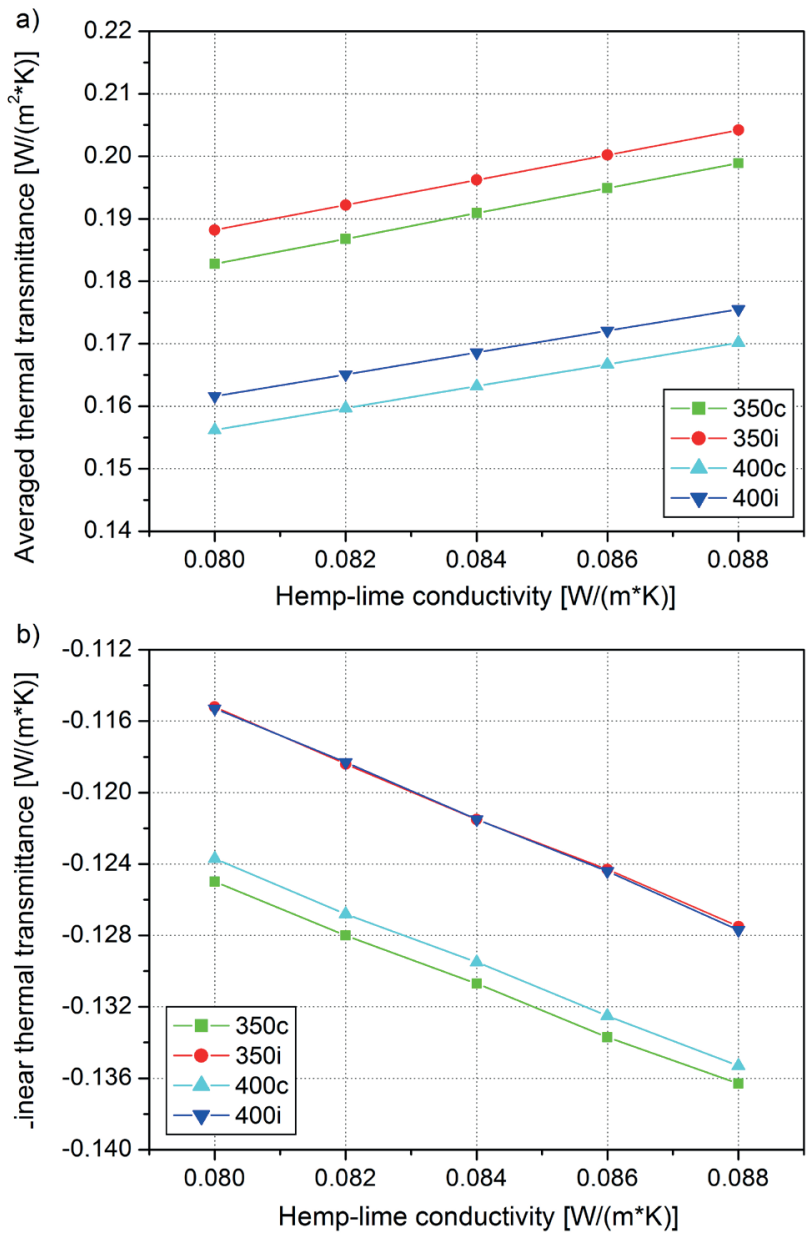

Fig. 12 Thermal properties of the wall external corner: a) U value averaged for the whole joint, b) linear thermal transmittance coefficients. Number in the legend denotes the wall thickness, $\mathrm{c}$ - central location of the timber frame, $\mathrm{i}$ - internal location of the timber frame

Placing the timber construction in the middle of the wall is a slightly better solution with regard to insulating properties. However, the difference is not significant (the thermal transmittance coefficient is lower by $0.1 \%$ (Fig. 10.a), and the influence of the timber studs on the linear thermal transmittance is slightly less pronounced (Fig. 10.b)). This may be connected with a smaller temperature gradient across the cross-section of the studs. A similar relationship can be seen when the heat transfer in the corner is taken into account (Fig. 11).

The thermal transmittance coefficient averaged for the whole length of the modelled walls' connection is by $2.7 \%$ to $3.5 \%$ smaller if the timber construction is placed in the central part of the wall (Fig. 12.a). The $\psi$ values are also lower for this solution (Fig. 12.b).

\subsubsection{Window placement in a wall (jamb)}

The simplest solution is placing the window jamb in the center of the strengthened (double) timber stud. The window can also be moved to the outer edge of the stud or mounted outside the main load-bearing construction with the use of an additional wooden frame. As different construction options would have an important influence on the heat flow patterns, this joint was analyzed in several versions. In addition to basic window placement (in the middle or at the outer edge of the construction frame - locations " 0 " and "1", respectively), the window was moved by $50 \mathrm{~mm}$ to the outer edge of the wall (locations "2" and further), as shown in the Fig. 13.

Along the window perimeter the jamb was insulated or not, doubling the number of the types of joints taken into account. Exemplary layout of the isotherms is shown in the Fig. 14. a)

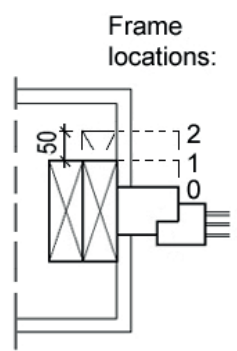

b)

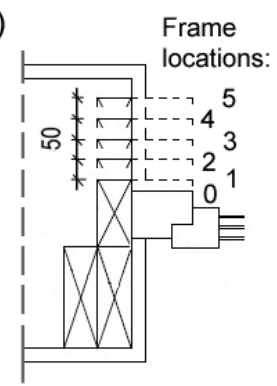

Fig. 13 Window frame locations in the two cases of timber construction placement: a) central, b) aligned with the inner plane (scale distorted)
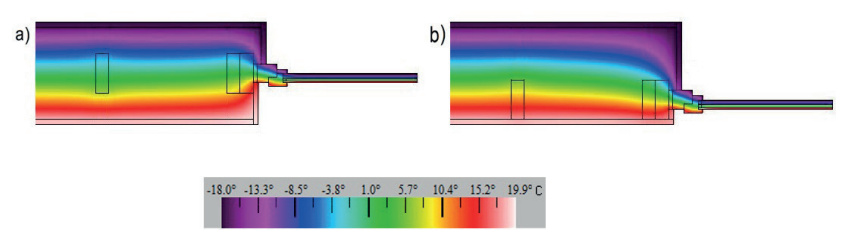

Fig. 14 Isotherms in the jamb in the two cases of timber frame location: a) central, b) aligned with the inner plane. Wall thickness: $350 \mathrm{~mm}$, hemp-lime conductivity: $0.080 \mathrm{~W} /(\mathrm{m} \cdot \mathrm{K})$, window frame location position " 0 ", case with a reveal 

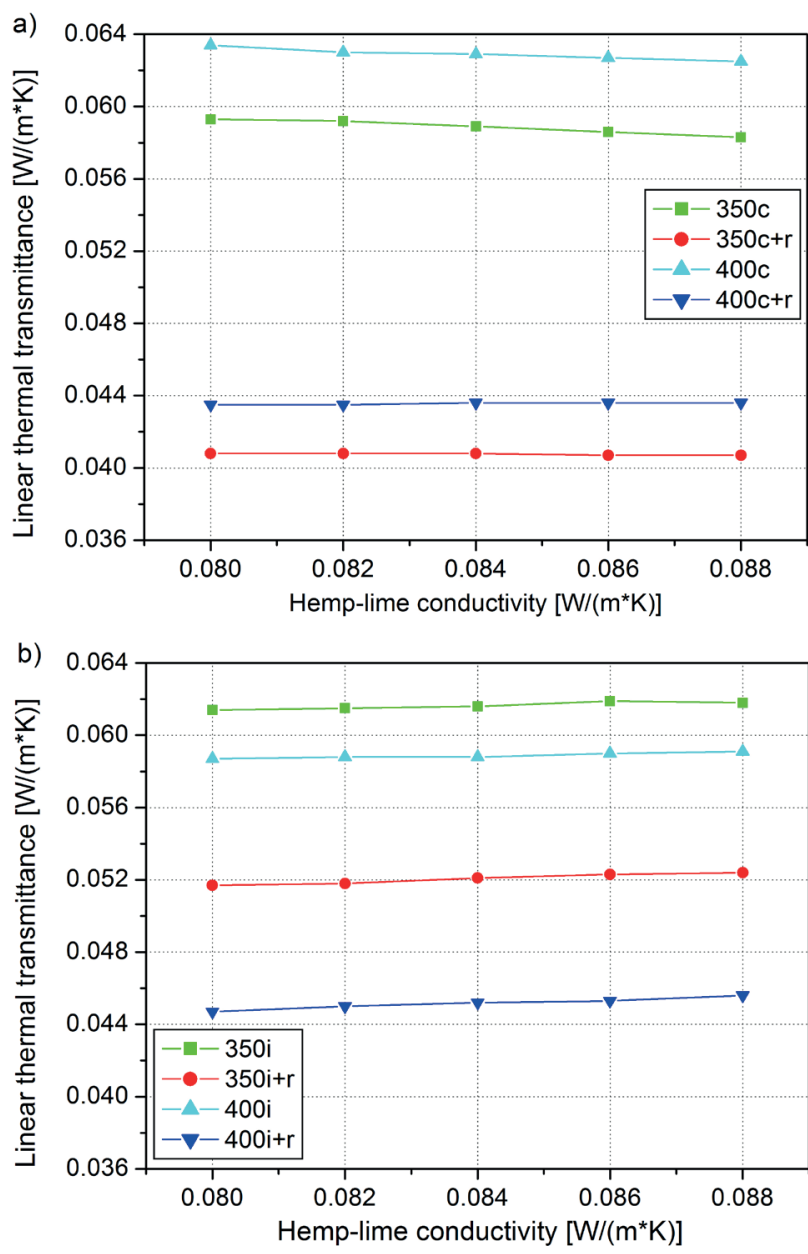

Fig. 15 Window jamb - linear thermal transmittance coefficients vs hemp-lime conductivity: a) timber construction and the window frame in the center of the wall (position " 0 "), b) timber construction in the inner part of the wall, the window frame in the position " 4 ". Number in the legend denotes the wall thickness, $\mathrm{c}$ - central location of the timber frame, $\mathrm{i}$ - internal location of the timber frame, $r$ - reveal

In this case the comparison of the joints was based only on the linear thermal transmittance coefficients to make it clearer (as the averaged thermal transmittance includes the heat transfer through the window and the wall). The coefficients do not depend significantly on the hemp-line conductivity, as was observed in the previous cases, and the graphs remain almost constant for a given type of joint (Fig. 15).

The joint construction, however, has a very important influence on the heat flow and the thermal quality of the connection. To show this relationship, $\psi$ values were plotted against the location of the window frame in the wall's cross-section (Fig. 16). For a clearer presentation, graphs were made only for the intermediate conductivity of the hemp-lime filling $(\lambda=0.084 \mathrm{~W} /(\mathrm{m} \cdot \mathrm{K}))$.
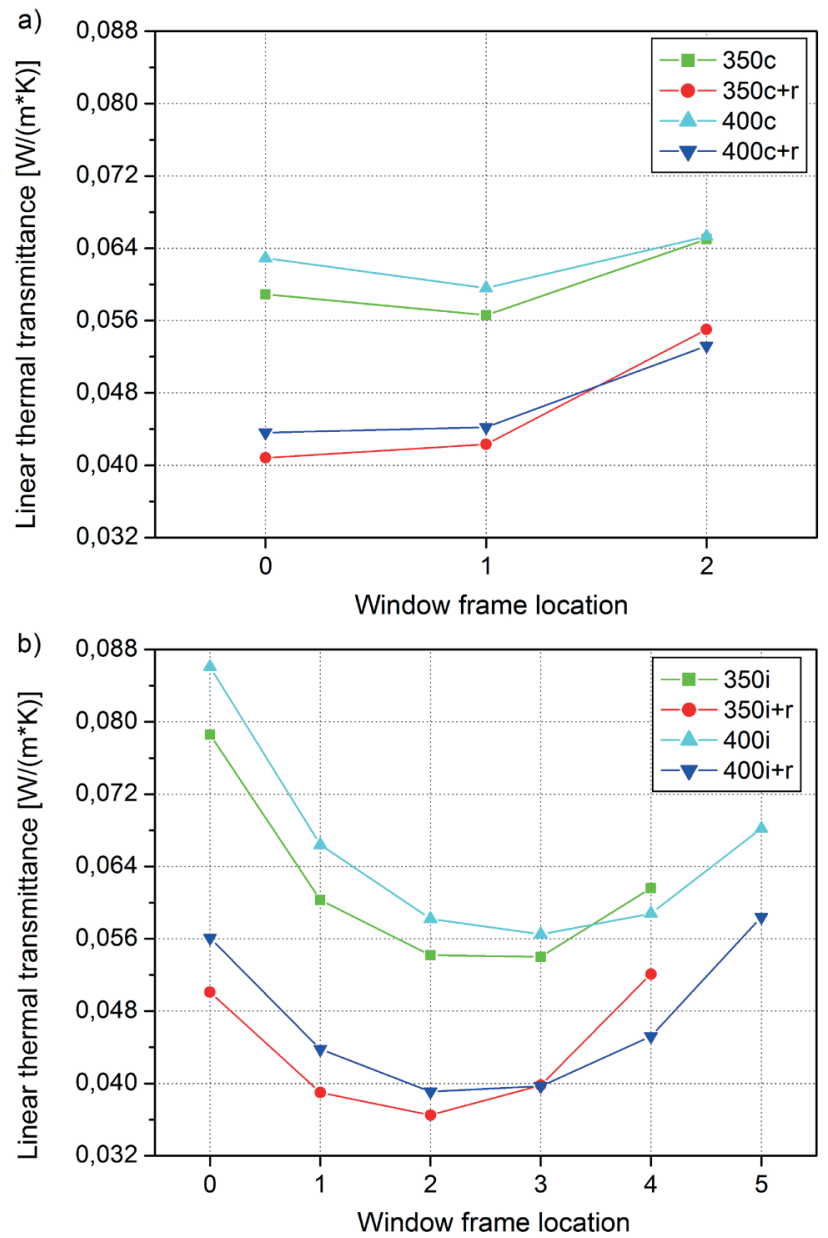

Fig. 16 Window jamb - linear thermal transmittance coefficients vs window location: a) timber construction in the center of the wall, b) timber construction in the inner part of the wall. Number in the legend denotes the wall thickness, $\mathrm{c}$ - central location of the timber frame, iinternal location of the timber frame, $r$ - reveal

When considering the wall with the load-bearing construction in the middle, the location of the window frame in the area of the timber studs is the most favorable (Fig. 16.a). For the uninsulated perimeter, the best option is placing the jamb closest to the studs' outer edge - this can reduce the linear thermal transmittance by approximately $3 \%$ to $6 \%$ compared with the window's central position. If the window perimeter is insulated, the central position reduces the thermal bridge the most, giving the lowest $\psi$ values of $0.0408 \mathrm{~W} /(\mathrm{m} \cdot \mathrm{K})$ and $0.0435 \mathrm{~W} /(\mathrm{m} \cdot \mathrm{K})$ for the walls $350 \mathrm{~mm}$ and $400 \mathrm{~mm}$ wide, respectively. Moving the windows to the outside increases the heat transfer in the joint, and the effect is more pronounced if the window perimeter is insulated.

For the wall with the load-bearing construction in its inner par, the results are different. Here, placing the window centrally over the timber studs is the worst case, 
giving the highest values of linear thermal transmittance (Fig. 16.b). While moving the window frame to the outside, the $\psi$ values gradually decrease and increase, reaching the minimum for the location extended by $100 \mathrm{~mm}$ from the outer edge of the studs (uninsulated perimeter) or by $50 \mathrm{~mm}$ (insulated perimeter). The outermost jamb placement is not the best solution because of the deeper penetration of the supporting timber structure into the insulating material. The benefits of proper window placement reach on average a $30 \%$ reduction of the linear thermal transmittance. It is worth noting that the lowest $\psi$ values obtained for this type of construction are smaller than in the previous case $(0.0365 \mathrm{~W} /(\mathrm{m} \cdot \mathrm{K})$ and $0.0391 \mathrm{~W} /(\mathrm{m} \cdot \mathrm{K})$ for the walls 350 and $400 \mathrm{~mm}$ wide, respectively).

Regardless of the wall type, the insulation of the frame perimeter decreases the heat losses by approximately $15 \%$ to $37 \%$, and the effect is strongest if the joints are of a poor thermal quality.

\subsubsection{Possibility of moisture condensation}

Moisture condensation on the internal surfaces of the elements may occur in the places where the temperature is lower than the dew point temperature. Thermal bridges are susceptible to this phenomenon because of the local temperature drop connected with the increase of heat transfer. The design for the avoidance of mold growth according to ISO 13788 [42] requires that in the critical area the temperature factor at the internal surface $f_{R s i}$ is higher than the design temperature factor $f_{R s i, \min }$ appointed for the critical month (which is the month with the highest $f_{R s i \text { min }}$ value). Both of the factors should be calculated using the increased thermal resistance at the internal surface $\left(R_{s i}=0.25 \mathrm{~W}(\mathrm{~m} \cdot \mathrm{K})\right)$ :

$f_{0.25}=\frac{\theta_{s i}-\theta_{e}}{\theta_{i}-\theta_{e}} \geq f_{0.25, \min }=\frac{\theta_{s i, \min }-\theta_{e}}{\theta_{i}-\theta_{e}}$,

where $\theta_{s i}$ is the surface temperature in the critical area $\left[{ }^{\circ} \mathrm{C}\right], \theta_{\text {si,min }}$ is the minimum acceptable surface temperature $\left[{ }^{\circ} \mathrm{C}\right], \theta_{i}$ is the internal temperature $\left[{ }^{\circ} \mathrm{C}\right], \theta_{e}$ is the external temperature $\left[{ }^{\circ} \mathrm{C}\right]$.

The temperature factors for the described junctions are presented in Table 5. As the values did not differ significantly in the analyzed range of the hemp-lime thermal conductivity, only the mean parameters are given.

National regulations in Poland accept using the design temperature factor $f_{0.25 \text {, min }}=0.72$, and in none of the joints does the risk of surface condensation occur. However, due to the construction type, differences in the surface tempera-
Table 5 Temperature factors $f_{025}$

\begin{tabular}{|c|c|c|c|c|c|}
\hline \multirow[t]{2}{*}{ No. } & \multirow[t]{2}{*}{ Type of joint } & \multicolumn{4}{|c|}{$\begin{array}{c}\text { Wall thickness and the location } \\
\text { of the timber frame }\end{array}$} \\
\hline & & $350 \mathrm{c}$ & $350 \mathrm{i}$ & $400 \mathrm{c}$ & $400 \mathrm{i}$ \\
\hline 1. & External corner & 0.88 & 0.86 & 0.89 & 0.87 \\
\hline 2. & $\begin{array}{c}\text { Window placement, } \\
\text { no reveal, } \\
\text { location "0" }\end{array}$ & 0.79 & 0.83 & 0.79 & 0.83 \\
\hline 3. & $\begin{array}{c}\text { Window placement, } \\
\text { no reveal, } \\
\text { location "1" }\end{array}$ & 0.79 & 0.82 & 0.79 & 0.83 \\
\hline 4. & $\begin{array}{c}\text { Window placement, } \\
\text { no reveal, } \\
\text { location "2" }\end{array}$ & 0.78 & 0.81 & 0.79 & 0.82 \\
\hline 5. & $\begin{array}{c}\text { Window placement, } \\
\text { no reveal, } \\
\text { location "3" }\end{array}$ & - & 0.80 & - & 0.81 \\
\hline 6. & $\begin{array}{c}\text { Window placement, } \\
\text { no reveal, } \\
\text { location "4" }\end{array}$ & - & 0.79 & - & 0.80 \\
\hline 7. & $\begin{array}{c}\text { Window placement, } \\
\text { no reveal, } \\
\text { location "5" }\end{array}$ & - & - & - & 0.79 \\
\hline 8. & $\begin{array}{c}\text { Window placement, reveal, } \\
\text { location " } 0 \text { " }\end{array}$ & 0.82 & 0.86 & 0.82 & 0.86 \\
\hline 9. & $\begin{array}{c}\text { Window placement, reveal, } \\
\text { location "1" }\end{array}$ & 0.81 & 0.85 & 0.81 & 0.85 \\
\hline 10. & $\begin{array}{c}\text { Window placement, reveal, } \\
\text { location "2" }\end{array}$ & 0.80 & 0.83 & 0.80 & 0.84 \\
\hline 11. & $\begin{array}{c}\text { Window placement, reveal, } \\
\text { location "3" }\end{array}$ & - & 0.82 & - & 0.83 \\
\hline 12. & $\begin{array}{c}\text { Window placement, reveal, } \\
\text { location " } 4 \text { " }\end{array}$ & - & 0.80 & - & 0.81 \\
\hline 13. & $\begin{array}{l}\text { Window placement, reveal, } \\
\text { location "5" }\end{array}$ & - & - & - & 0.80 \\
\hline
\end{tabular}

tures and temperature factors can be observed. As far as the external corners are concerned, central placement of the load-bearing frame is more favorable, giving higher temperature factors. The opposite regularity can be seen in the case of window placement - here the internal position of the frame is a better solution, as the bigger width of the external insulating material layer increases temperature on the internal surfaces (using a reveal has the same effect). Moving the window to the outside lowers the temperature factors and the internal temperatures, because of a deeper penetration into the wall structure of additional timber studs used for window installation.

\section{Conclusions}

Despite relatively good insulating properties, timber elements have a noticeable influence on the local increase of the heat transfer in hemp-lime composite structures, 
forming thermal bridges in the partitions themselves and in the construction nodes. However, linear thermal transmittance coefficients in the presented joints were not very high. For the connections of opaque elements they did not exceed $0.01 \mathrm{~W} /(\mathrm{m} \cdot \mathrm{K})$, the value demanded for passive houses [43]. The window placements turned out to be the weakest node, mainly because of the major geometry changes and different thermal properties of particular elements. Nevertheless, the linear thermal transmittance coefficients varied here from approximately 0.035 to $0.090 \mathrm{~W} /(\mathrm{m} \cdot \mathrm{K})$, and this can be regarded as a good result. Generally, it can be concluded that despite the occurrence of thermal bridges, hemp-lime building structures can be sufficiently protected from excessive heat losses and surface moisture condensation thanks to proper design decisions.

On the basis of the presented analyses it is difficult to decide which type of construction is a better solution with regard to thermal bridges. The external corners have a better thermal quality if the load-bearing structure is located in the middle of the wall. The window placement turned out to be a very specific construction detail, where a lot depends on the shaping of the wooden reinforcement and the reveal. However, the wall with an internal timber frame seems to be the construction type having a bigger potential for minimizing heat losses, making it possible to achieve the lowest linear thermal transmittance coefficients.

The final assessment of the influence of thermal bridges should be connected with the whole building energy analyses, as the heat losses through the envelope depend not only on the linear thermal transmittance, but also on the length of the specific joints in the building's structure. To continue the research, thermal simulations could be supplemented with heat-air-moisture (HAM) simulations investigating the effect of moisture on heat losses.

\section{Acknowledgement}

This work was financially supported by Ministry of Science and Higher Education in Poland, within the statutory research number $\mathrm{S} / 14 / 2018$.

\section{References}

[1] Brás, A., Gonçalves, F., Faustino, P. "Cork-based mortars for thermal bridges correction in a dwelling: Thermal performance and cost evaluation", Energy and Buildings, 72, pp. 296-308, 2014. https://doi.org/10.1016/j.enbuild.2013.12.022

[2] Theodosiou, T. G., Papadopoulos, A. M. "The impact of thermal bridges on the energy demand of buildings with double brick wall construction", Energy and Buildings, 40(11), pp. 2083-208, 2008. https://doi.org/10.1016/j.enbuild.2008.06.006
[3] Larbi, A. B. "Statistical modelling of heat transfer for thermal bridges of buildings", Energy and Buildings, 37(9), pp. 945-951, 2005. https://doi.org/10.1016/j.enbuild.2004.12.013

[4] Ascione, F., Bianco, N., De Masi, R. F., Vanoli, G. P. "Rehabilitation of the building envelope of hospitals: Achievable energy savings and microclimatic control on varying the HVAC systems in Mediterranean climates", Energy and Buildings, 60, pp. 125-138, 2013. https://doi.org/10.1016/j.enbuild.2013.01.021

[5] Rossi, F., Pisello, A. L., Nicolini, A., Filipponi, M., Palombo, M. "Analysis of retro-reflective surfaces for urban heat island mitigation: A new analytical model", Applied Energy, 114, pp. 621-631, 2014. https://doi.org/10.1016/j.apenergy.2013.10.038

[6] GhaffarianHoseini, A., Dahlan, N. D., Berardi, U., GhaffarianHoseini, A., Makaremi, N., GhaffarianHoseini, M. "Sustainable energy performances of green buildings: A review of current theories, implementations and challenges", Renewable and Sustainable Energy Reviews, 25, pp. 1-17, 2013.

https://doi.org/10.1016/j.rser.2013.01.010

[7] CEN "ISO 10456 Building materials and products. Hygrothermal properties. Tabulated design values and procedures for determining declared and design thermal values", International Organization for Standardization, Geneva, Switzerland, 2007.

[8] Wasilewska, A., Pietruszka, B. "Study of thermal conductivity coefficient of straw bales", Institute of Building Technology, Warsaw, Poland, 2015.

[9] Brzyski, P., Barnat-Hunek, D., Suchorab, Z., Łagód, G. "Composite Materials Based on Hemp and Flax for Low-Energy Buildings", Materials, 10(5), pp. 510-533, 2017. https://doi.org/10.3390/ma10050510

[10] Labat, M., Magniont, C., Oudhof, N., Aubert, J.-E. "From the experimental characterization of the hygrothermal properties of straw-clay mixtures to the numerical assessment of their buffering potential", Building and Environment, 97, pp. 69-81, 2016. https://doi.org/10.1016/j.buildenv.2015.12.004

[11] Gross, C., Walker, P. "Racking performance of timber studwork and hemp-lime walling", Construction and Building Materials, 66, pp. 429-435, 2014.

https://doi.org/10.1016/j.conbuildmat.2014.05.054

[12] Arnaud, L., Gourlay, E. "Experimental study of parameters influencing mechanical properties of hemp concrete", Construction and Building Materials, 28(1), pp. 50-56, 2012. https://doi.org/10.1016/j.conbuildmat.2011.07.052

[13] Benfratello, S., Capitano, C., Peri, G., Rizzo, G., Scaccianoce, G., Sorrentino, G. "Thermal and structural properties of a hemp-lime biocomposite", Construction and Building Materials, 48, pp. 745$754,2013$.

https://doi.org/10.1016/j.conbuildmat.2013.07.096

[14] Elfordy, S., Lucas, F., Tancret, F., Scudeller, Y., Goudet, L. "Mechanical and thermal properties of lime and hemp concrete ("hempcrete") manufactured by a projection process", Construction and Building Materials, 22(10), pp. 2116-2123, 2008. https://doi.org/10.1016/j.conbuildmat.2007.07.016

[15] Walker, R., Pavía, S., Mitchell, R. "Mechanical properties and durability of hemp-lime concretes", Construction and Building Materials, 61, pp. 340-348, 2014. https://doi.org/10.1016/j.conbuildmat.2014.02.065 
[16] de Bruijn, P. B., Jeppsson, K.-H., Sandin, K., Nilsson, C. "Mechanical properties of lime-hemp concrete containing shives and fibres", Biosystems Engineering, 103(4), pp. 474-479, 2009. https://doi.org/10.1016/j.biosystemseng.2009.02.005

[17] Strandberg-de Bruijn, P. B., Johansson, P. "Moisture transport properties of lime hemp concrete determined over the complete moisture range", Biosystem Engineering, 122, pp. 31-41, 2014. https://doi.org/10.1016/j.biosystemseng.2014.03.001

[18] Walker, R., Pavía, S. "Moisture transfer and thermal properties of hemp-lime concretes", Construction and Building Materials, 64, pp. 270-276, 2014.

https://doi.org/10.1016/j.conbuildmat.2014.04.081

[19] Barclay, M., Holcroft, N., Shea, A. D. "Methods to determine whole building hygrothermal performance of hemp-lime buildings", Building and Environment, 80, pp. 204-212, 2014. https://doi.org/10.1016/j.buildenv.2014.06.003

[20] Rahim, M., Douzane, O., Tran Le, A. D., Promis, G., Laidoudi, B., Crigny, A., Dupre, B., Langlet, T. "Characterization of flax lime and hemp lime concretes: Hygric properties and moisture buffer capacity", Energy and Buildings, 88, pp. 91-99, 2015. https://doi.org/10.1016/j.enbuild.2014.11.043

[21] Rahim, M., Douzane, O., Tran Le, A. D., Promis, G., Langlet, T. "Characterization and comparison of hygric properties of rape straw concrete and hemp concrete", Construction and Building Materials, 102(1), pp. 679-687, 2016.

https://doi.org/10.1016/j.conbuildmat.2015.11.021

[22] Stevulova, N., Kidalova, L., Cigasova, J., Junak, J., Sicakova, A., Terpakova, E. "Lightweight composites containing hemp hurds", Procedia Engineering, 65, pp. 69-74, 2013. https://doi.org/10.1016/j.proeng.2013.09.013

[23] Collet, F., Pretot, S. "Thermal conductivity of hemp concretes: variation with formulation, density and water content", Construction and Building Materials, 65, pp. 612-619, 2014. https://doi.org/10.1016/j.conbuildmat.2014.05.039

[24] de Bruijn, P., Johansson, P. "Moisture fixation and thermal properties of lime-hemp concrete", Construction and Building Materials, 47, pp. 1235-1242, 2013 https://doi.org/10.1016/j.conbuildmat.2013.06.006

[25] Sassoni, E., Manzi, S., Motori, A., Montecchi, M., Canti, M. "Novel sustainable hemp-based composites for application in thebuilding industry: physical, thermal and mechanical characterization", Energy and Buildings, 77, pp. 219-226, 2014. https://doi.org/10.1016/j.enbuild.2014.03.033

[26] Shea, A., Lawrence, M., Walker, P. "Hygrothermal performance of an experimental hemp-lime building", Construction and Building Materials, 36, pp. 270-275, 2012. https://doi.org/10.1016/j.conbuildmat.2012.04.123

[27] Maalouf, C., Tran Le, A. D., Umurigirwa, S. B., Lachi, M., Douzane, O. "Study of hygrothermal behaviour of a hemp concrete building envelope under summer conditions in France", Energy and Buildings, 77, pp. 48-57, 2014. https://doi.org/10.1016/j.enbuild.2014.03.040

[28] Tran Le, A. D., Maalouf, C., Mai, T. H., Wurtz, E., Collet, F. "Transient hygrothermal behaviour of a hemp concrete building envelope", Energy and Buildings, 42(10), pp. 1797-1806, 2010. https://doi.org/10.1016/j.enbuild.2010.05.016
[29] Barnat-Hunek, D., Smarzewski, P., Brzyski, P. "Properties of hempflax composites for use in the building industry", Journal of Natural Fibres, 14(3), 410-425, 2017. https://doi.org/10.1080/15440478.2016.1212764

[30] ANSI "ISO 8302 Thermal insulation. Determination of steady-state thermal resistance and related properties. Guarded hot plate apparatus", International Organization for Standardization, Geneva, Switzerland, 1991.

[31] Bevan, R., Wooley, T. "Hemp lime construction - a guide to building with hemp lime composites", 1st ed., IHS BRE Press, Bracknell, United Kingdom, 2008.

[32] Allin, S. "Building with hemp", 2nd ed., Seed Press, Kenmare, Ireland, 2012

[33] Stanwix, W., Sparrow, A. "The hempcrete book. Designing and building with hemp-lime", 1st ed., Totnes, United Kingdom, 2014.

[34] Windows and Daylighting Building Technology and Urban Systems, [online] Available at: http://windows.lbl.gov/software, [Accessed: 29.05.2017]

[35] Windows and Daylighting Group "Therm 6.3 / Window 6.3 NFRC Simulation Manual", [pdf] Lawrence Berkeley National Laboratory, Berkeley, California, USA, 2011. [online] Available at: https://c.ymcdn.com/sites/nfrecommunity.site-ym.com/resource/ resmgr/2014_Technical_Docs/NFRCSim6.3-May2015.pdf [Accessed: 04.02.2019]

[36] Real, S., Gomes, M. G., Rodrigues, A. M., Bogas, J. A. "Contribution of structural lightweight aggregate concrete to the reduction of thermal bridging effect in buildings", Construction and Building Materials, 121, pp. 460-470, 2016. https://doi.org/10.1016/j.conbuildmat.2016.06.018

[37] Murad, C., Doshi, H., Ramakrishnan, R. "Impact of Insulated Concrete Curb on Concrete Balcony Slab", Procedia Engineering, 118, pp. 1030-1037, 2015.

https://doi.org/10.1016/j.proeng.2015.08.545

[38] Cappelletti, F., Gasparella, A., Romagnoni, P., Baggio, P. "Analysis of the influence of installation thermal bridges on windows performance: the case of clay block walls", Energy and Buildings, 43(6), pp. 1435-1442, 2011. https://doi.org/10.1016/j.enbuild.2011.02.004

[39] Stazi, F., Tomassoni, E., Bonfigli, C., Di Perna, C. "Energy, comfort and environmental assessment of different building envelope techniques in a Mediterranean climate with a hot dry summer", Applied Energy, 134, pp. 176-196, 2014. https://doi.org/10.1016/j.apenergy.2014.08.023

[40] "ISO 15099 Thermal performance of windows, doors and shading devices. Detailed calculations", International Organization for Standardization, Geneva, Switzerland, 2003.

[41] "ISO 10211 Thermal bridges in building construction. Heat flows and surface temperatures. Detailed calculations", International Organization for Standardization, Geneva, Switzerland, 2007.

[42] "ISO 13788 Hygrothermal performance of building components and building elements. Internal surface temperature to avoid critical surface humidity and interstitial condensation. Calculation methods", International Organization for Standardization, Geneva, Switzerland, 2012.

[43] Strom, I., Joosten, L., Boonstra, Ch. "Passive Houses Solutions", [pdf] Intelligent Energy Europe, Brussels, Belgium, 2006. [online] Available at: http://erg.ucd.ie/pep/pdf/Passive_House_Sol_English. pdf [Accessed: 05.02.2019] 